\title{
Pengembangan Modul Pembelajaran Matematika Berbasis Etnomatematika Menggunakan Metode Inkuiri
}

\author{
Siti Mardiah ${ }^{1}$, Rany widyastuti², Achi Rinaldi ${ }^{2}$ \\ ${ }^{1}$ SMK Gemakarya Lampung, Dusun Sumber Bakti, Desa Sinar Rezeki, Jati Agung, Lampung \\ Selatan, Indonesia \\ 2 Universitas Islam Negeri Raden Intan Lampung, Jalan Endro Suratmin, Sukarame, Bandar \\ Lampung 35133, Indonesia \\ *Corresponding Author. E-mail: sitimardiahsh@gmail.com, Telp: +6285609135301
}

Received : 02-02-2018; Revised : 08-05-2018; Accepted : 28-05-2018

\begin{abstract}
Abstrak
Penelitian ini bertujuan untuk mengetahui bagaimana pengembangan modul pembelajaran matematika berbasis etnomatematika menggunakan metode inkuiri, serta untuk mengetahui respon guru dan siswa terhadap pengembangan modul pembelajaran matematika berbasis etnomatematika menggunakan metode inkuiri. Metode penelitian ini adalah Research and Development (R\&D) menggunakan model 4D. Hasil validasi tahap 1 oleh ahli materi diperoleh rata-rata sebesar 65,36\% dengan kriteria "cukup baik" sehungga pelu adanya evisi modul. Pada validasi tahap 2 diperoleh rata-rata sebesar 84,02\% dengan kriteria "baik", sehingga tidak ada revisi ulang terhadap modul. Hasil validasi tahap 1 oleh ahli media sebesar $60 \%$ dengan kiteria "cukup Baik" yang artinya perlu adanyanya revisi dibeberapa bagian modul. Pada validasi tahap 2 diperoleh rata-rata sebesar 86,66\% dengan kriteria "sangat baik" sehingga modul dikatakan valid dan siap digunakan untuk ujicoba lapangan. Berdasarkan hasil penelitian respon guru terhadap modul diperoleh rata-rata sebesar $86,15 \%$ dengan kriteria "sangat menarik". Pada uji coba kelompok kecil didapat rata-rata sebesar $85 \%$ dengan kriteria menarik dan uji coba kelompok besar memperoleh rata-rata $87,28 \%$ dengan kriteria sangat menarik sehingga modul layak dan siap digunakan sebagai bahan ajar.
\end{abstract}

Kata Kunci : Pengembangan Modul, Etnomatematika, Metode Inkuiri

\begin{abstract}
This research entitled Development of Mathematics Based Module of Ethnomatematics using Inkuiri method. This study aims to find out how the development of mathematics learning module based on etnomatematics using inquiry method, and to know teacher and student response to the development of mathematics learning module based on etnomatematics using inquiry method. This research method is Research and Development (R\&D) using $4 D$ model. Based on the results of validation of stage 1 by the material experts obtained a comulative average of 65.36\% with the criteria of "good enough" which means that there is an improvement of some aspects contained in the module. After performing a series of revisions, the average score of cumulative of $84.02 \%$ validation with "good" criterion was obtained, so there is no revision of the module. The average score of cumulative validation of stage 1 by a media expert is $60 \%$ with a "good enough" code which means that it needs to be revised in some parts of the module. In the second stage of validation, the average cultivation is $86.66 \%$ with "very good" criteria so that the module is valid and ready for field trial. From the results of research teacher response to the module obtained average of $86.15 \%$ with the criteria "very interesting". In the small group trial the average of $85 \%$ was obtained with interesting criteria and large group trial obtained an average of $87.28 \%$ with very interesting criteria so that the module is feasible and ready to be used as teaching materials.
\end{abstract}

Keywords: Module Development, Ethnomatematics, Inquiry Method 
Desimal, 1 (2), 2018 - 120

Siti Mardiah, Rany Widyastuti, Achi Rinaldi

\section{PENDAHULUAN}

Pendidikan sangat penting bagi setiap individu baik bagi kepentingan pribadi maupun dalam kedudukannya sebagai warga negara (Anggoro, 2015). Pengaplikasian ilmu pendidikan tersebut dikaitkan dengan perkembangan ilmu pengetahuan dan teknologi namun tetap sejalan dengan tujuan pendidikan nasional dan tujuan Kurikulum 2013 (S. Wijayanti, 2017). Tujuan pendidikan nasional melingkupi aspek kognitif dan psikomotor dan aspek afektif. Demikian pula tujuan dalam kurikulum 2013 disebutkan bahwa pengembangan sikap spiritual dan sosial, rasa ingin tahu, kreativitas, dan kerja sama dilakukan secara seimbang dengan pengembangan kemampu-an intelektual dan psikomotorik (Musfiqi \& Jailani, 2014).

Hal yang sangat penting dalam proses pembelajaran matematika adalah dalam pemecahan masalah yang merupakan jantungnya matematika (Widyastuti, 2015). Dalam memahami pelajaran matematika siswa sering mengalami kesulitan belajar sehingga menyebabkan hasil belajar yang rendah. Rendahnya hasil belajar yaitu pemilihan metode dan media pembelajaran yang kurang tepat (Ade, 2017). Proses pembelajaran matematika haruslah memiliki kelengkapan pembelajaran yang memadai agar kegiatan belajar mengajar di kelas berjalan sesuai dengan kompetensi dasar yang diharapkan (Supriadi, 2015). Oleh karena peneliti menyatakan perlu diadakannya pengembangan media pembelajaran salah satunya dengan mengembangan modul pembelajaran matematika berbasis etnomatematika menggunakan metode inkuiri.

Penelitian yang serupa dilakukan oleh Sri Asnawati tentang penerapan pembelajaran inkuiri dengan etnomatematika. Tujuan dari penelitian ini adalah menelaah peningkatan kemampuan pemahaman matematis siswa yang memperoleh pembelajaran inkuiri dengan etnomatematik dan siswa yang memperoleh pembelajaran konvensional pada materi bidang datar. Berdasarkan hasil observasi yang dilakukannya diketahui bahwa pembelajaran etnomatematika berjalan dengan baik dan mampu menciptakan suasana belajar yang menarik, dengan budaya yang dimunculkan serta membuat siswa termotivasi, dan membuat siswa aktif dalam kegiatan belajar mengajar disbanding dengan pembelajaran secara konvensional (Asnawati, Liliana, \& Muhtarulloh, 2014). Menurut Nurusaniah pada penelitiannya tentang pembelajaran inkuiri diketahui bahwa pembelajaran inkuiri membuat siswa belajar lebih baik, hal ini karena pembelajaran menggunakan inkuiri dapat meningkatkan ketrampilan proses sains pada siswa. Artinya siswa akan lebih kreatif dalam menyelesaikan soal tentang sains (Trisianawati \& Sari, 2017).

Ismu Fatikhah, dan Nurma Izzati pada penelitiannya tentang pengembangan modul menyatakan bahwa dengan mengembangkan modul siswa dapat belajar dengan mandiri sesuai metode yang digunakan dalam pembuatan modul (Fatikhah \& Izzati, 2015). selain itu, Andista Candra Yusro dan Mislan Sasono dalam penelitiannya tentang pengembangan modul menggunakan metode inkuiri diperoleh kesimpulan bahwa modul yang mengguankan metode inkuiri dapat membantu proses kemandirian siswa dalam belajar (Yusro \& Sasono, 2016).

Terdapat perbedaan antara penelitian di atas dengan penelitian yang dilakukan oleh peneliti diantaranya penelitian oleh Sri Asnawati belum dikaitkan dengan pengembangan modul, dan materi serta metode penelitian yang digunakannya pun berbeda. Pada penelitian Nurussaniah perbedaan yang mendasar adalah belum dikaitkannya penelitian ini dengan pengembangan 
Desimal, 1 (2), 2018 - 121

Siti Mardiah, Rany Widyastuti, Achi Rinaldi

modul serta penggunaan etnomatematika, serta materi pembelajarannya pun berbeda. Pada penelitian Nurma Izati modul yang dikembangkan belum berbasis etnomatematika dengan menggunakan metode inkuiri, serta Andista Candra Yusro dan Mislan Sasono diketahui bahwa belum terdapat kaitan antara penelitian yang dilakukan dengan etnomatematika.

Sedangkan pada penelitian yang dilakukan ini terdapat pembaharuan dimana pada penelitian yang dilakukan peneliti membuat sebuah modul berbasis etnomatematika menggunakan metode inkuiri yang disusun menggunakan langkah-langkah metode inkuiri pada sub bab bangun datar. Modul yang disususun ini berbasis budaya yang ada pada masyarakat Lampung. Tujuan dari pengembangan modul ini yaitu membuat siswa tertarik dalam pembelajaran yang berbasis budaya dan dapat membantu siswa menemukan konsep matematika sendiri. Selain itu, siswa diharapkan juga dapat mengetahui penerapan matematika terhadap kebudayaan Lampung.

\section{METODE}

Dalam penelitian ini menggunakan metode penelitian dan pengembangan (Research and Development) yaitu metode penelitian untuk menghasilkan produk pendidikan, dan menguji keefektifan produk tersebut dalam bidang pendidikan (Novitasari, Masykuri, \& Aminah, 2016). Model pengembangan modul yang digunakan adalah model Thiagarajan. Model Thiagarajan terdiri dari 4 tahap yang dikenal dengan model 4D (four $D$ model). Keempat tahap tersebut adalah tahap pendefinisian (define), tahap perencanaan (design), tahap pengembangan (development) dan tahap penyebaran (disseminate) (Rosa, 2015). Pengembangan dilaksanakan pada mata pelajaran matematika, sub bab bangun datar. Berikut pedoman pensekoran pada penelitian ini yang dilakukan menggunakan skala likert (Sugiyono, 2013):

Tabel 1. Pedoman Skor Penilaian

\begin{tabular}{ll}
\hline Kriteria & Skor \\
Sangat Baik (SB) & 5 \\
Baik (B) & 4 \\
Cukup baik (CB) & 3 \\
Kurang (K) & 2 \\
Sangat Kurang (SK) & 1 \\
\hline
\end{tabular}

Selanjutnya dilakukan perhitungan tiap butir pertanyaan menggunakan rumus sebagai berikut :

$$
\mathrm{P}=\frac{\sum x}{\text { skor maksimal }} \times 100 \%
$$

Keterangan :

$\mathrm{P} \quad=$ Persentase kelayakan

$\sum x=$ jumlah skor

Langkah terakhir adalah menyimpulkan hasil perhitungan berdasarkan aspek dengan melihat Tabel 3.2 di bawah ini:

Tabel 2. Range Persentase Dan Kriteria Kulitatif Modul

\begin{tabular}{ll}
\hline Skor Persentase & Interpretasi \\
$85 \%<\mathrm{P} \leq 100 \%$ & Sangat baik \\
$70 \%<\mathrm{P} \leq 85 \%$ & Baik \\
$55 \%<\mathrm{P} \leq 70 \%$ & Cukup baik \\
$50 \%<\mathrm{P} \leq 55 \%$ & Kurang \\
$0 \% \leq \mathrm{P} \leq 50 \%$ & Sangat kurang \\
\hline
\end{tabular}

Produk pengembangan akan berakhir saat skor penilaian terhadap modul ini telah memenuhi syarat kelayakan dengan tingkat kesesuaian materi dan desain, dikategorikan sangat menarik atau manarik.

\section{HASIL DAN PEMBAHASAN}

Hasil pengembangan yang dilakukan oleh peneliti ini adalah menghasilkan Modul pembelajaran matematika berbsis etnomatematika menggunakan metode inkuiri. Penelitian dan pengembangan ini dilakukan dengan menggunakan prosedur dan pengembangan $4 \mathrm{D}$ yang dilakukan dari 
Desimal, 1 (2), 2018 - 122

Siti Mardiah, Rany Widyastuti, Achi Rinaldi

tahap pendefinisian (Define), tahap perencanaan (Design), tahap pengembangan (Develop), dan tahap penyebaran (Disseminate). Data hasil setiap tahapan prosedur penelitian dan pengembangan yang dilakukan adalah sebagai berikut:

\section{Define}

Tahap define adalah tahap pendefinisian dalam sebuah penelitian biasa disebut dengan analisis kebutuhan. Pada tahap ini mencakup empat langkah pokok yaitu:

a. Analisis font end

Analisis Front-end (front-end analysis) dilakukan dengan tiga langkah yaitu observasi kegiatan pembelajaran, wawancara dengan guru matematika, dan observasi perangkat pembelajaran yang digunakan. Hasil wawancara dengan guru matematika diketahui bahwa bahan ajar yang digunakan hanya berisi materi, contoh soal, dan soal-soal yang masih monoton dan tidak sesuai kebutuhan siswa artinya dalam bahan ajar tersebut belum memuat aktifitas belajar yang melibatkan siswa secara langsung dalam menemukan dan menerapkan konsep matematika. Berdasarkan hasil studi pendahuluan diketahui bahwa siswa masih mengalami kesulitan dalam memahami konsep bangun datar.

b. Analisis konsep (concept analysis)

Pada penelitian yang dilakukan oleh peneliti siswa tertarik pada pembelajaran berbasis budaya. Selain itu siswa juga tertarik pada metode pembelajaran yang dapat mendorong mereka untuk menemukan konsep matematika sendiri yang dapat dilakukan menggunakan metode inkuiri. Analisis konsep yang telah dilakukan pada penelitian ini adalah dengan mengidentifikasi bagian-bagian penting dan utama yang akan dipelajari dan menyusunnya dalam bentuk yang sistematis dan relevan yang akan masuk pada modul pembelajaran. Berdasarkan analisis Front-end yaitu prasyarat, petunjuk penggunaan, Kompetensi Isi (KI), Kompetensi Dasar (KD) dan kriteria keberhasilan modul pembelajaran matematika berbasis etnomatematika menggunakan metode inkuiri. Hal ini didukung oleh hasil wawancara dengan Ibu Rinayati S.Pd selaku guru Matematika. Beliau menyatakan bahwa beliau belum mengembangkan modul pembelajaran matematika berbasis etnomatematika menggunakan metode inkuiri sebagai bahan ajar pendukung pembelajaran.

c. Analisis tugas (task analysis)

Selanjutnya setelah analisis konsep (concept analysis) dilanjutkan dengan analisis tugas (task analysis). Pada analisis tugas dilakukan analisis kompetensi dasar kemudian menjabarkan indikator pembelajaran. Peneliti menganalisis tugas-tugas pokok yang harus dikuasai siswa agar siswa dapat mencapai kompetensi minimal. Berdasarkan hasil analisis diperoleh gambaran mengenai tugas-tugas yang diperlukan dalam proses pembelajaran yang sesuai dengan kompetensi dasar.

d. Perumusan Tujuan Pembelajaran (specifying instructional objectives)

Berdasarkankan hasil analisis front-end, analisis konsep dan analisis tugas kemudian peneliti 
Desimal, 1 (2), 2018 - 123

Siti Mardiah, Rany Widyastuti, Achi Rinaldi

menyusun tes dan merancang bahan ajar yang kemudian diintegrasikan kedalam materi bahan ajar. Selanjutnya peneliti melakukan analisis tujuan pembelajaran. Berdasarkan analisis tujuan pem-belajaran diperoleh data pada Tabel 3 berikut:

Tabel 3. Analisis Tujuan Pembelajaran

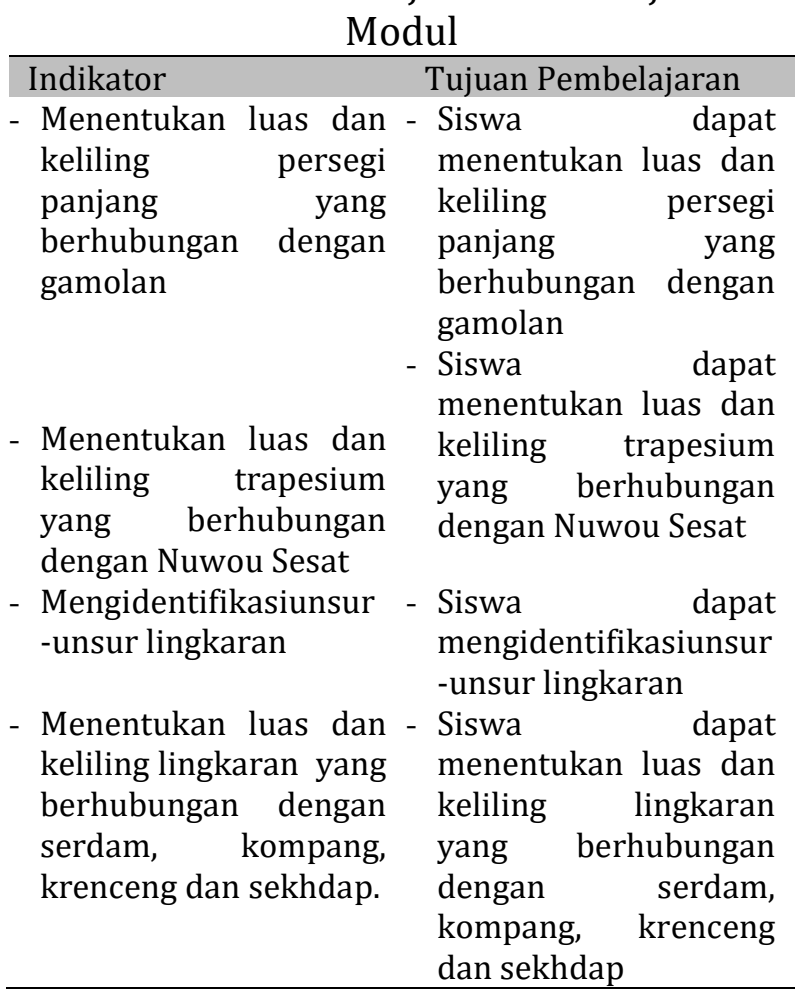

\section{Design}

Perancangan ini bertujuan guna merancang bahan ajar guna memperoleh draf awal. Bahan ajar yang akan dikembangkan yaitu modul pembelajaran matematika berbasis etnomatematika menggunakan metode inkuiri. Langkahlangkah penyusunan desain produk modul ini, diantaranya adalah menyesuaikan KD (Kompetensi dasar) dengan indikator berdasarkan kurikulum K13.

\section{Develop}

\begin{tabular}{lr}
\multicolumn{3}{r}{ Kelayakan produk pengembangan } \\
modul pembelajaran & berbasis \\
etnomaematika menggunakan metode
\end{tabular} inkuiri dinilai oleh 6 orang ahli yang terdiri dari 3 orang ahli media dan 3 orang ahli materi. Adapun ketentuanketentuan dalam memilih subyek ahli yaitu: 1) berpengalaman dibidangnya, 2) berpendidikan minimal S2 atau sedang menempuh pendidikan S2. Validasi atau penilaian kelayakan juga dilakukan oleh 2 orang praktisi yaitu guru matematika, dengan kriteria: 1) berpengalaman dibidangnya, 2) berpendidikan minimal S1, 3) merupakan guru matematika.

Berdasarkan penilaian validasi ahli materi terhadap modul pembelajaran berbasis etnomaematika menggunakan metode inkuiri dianalisis 4 aspek yaitu kualitas isi, aspek ketepatan cakupan, metode inkuiri, dan bahasa. Pada penilaian validasi ahli media dianalisis 3 aspek yaitu aspek ukuran modul, desain kulit modul, dan desain isi modul. Pada penelitian ini setelah dilakukan validasi oleh para ahli, langkah selanjutnya yaitu revisi desain. Setelah itu dilakukan uji coba produk kepada siswa terhadap modul pembelajaran berbasis etnomaematika menggunakan metode inkuiri.

a. Validasi

1) Hasil Validasi Ahli Materi

Hasil validasi ahli materi pada produk disajikan dalam bentuk grafik berikut:

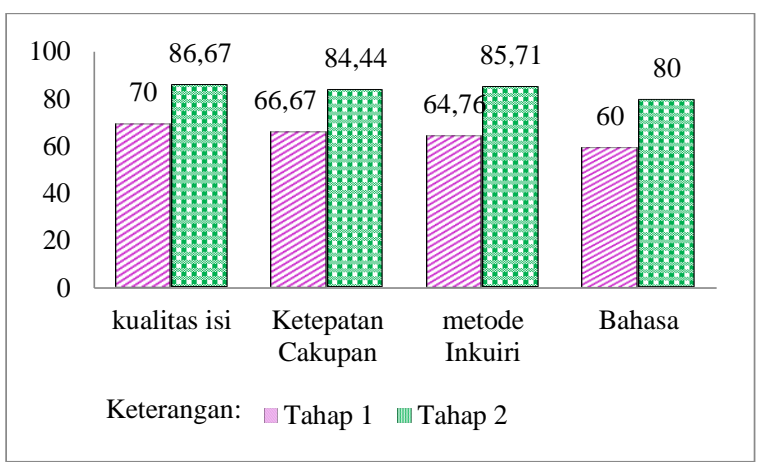

Gambar 1. Hasil validasi ahli materi

Berdasarkan Gambar 1 diketahui bahwa hasil penilaian validasi ahli materi tahap 1 dan tahap 2 sebagai berikut: Pada 
aspek kualitas isi pada tahap 1 diperoleh rata-rata sebesar 70 dengan kriteria "baik" dan pada tahap 2 rata-rata kualitas isi sebesar 86,67 dengan kriteria "sangat baik". Aspek ketepatan cakupan pada tahap 1 diperoleh rata-rata sebesar 66,67 dengan kriteria "cukup baik" dan pada tahap 2 diperoleh rata-rata sebesar 84,44 dengan kriteria "baik". Rata-rata tahap 1 aspek metode inkuiri sebesar 64,76 dengan kriteria "cukup baik" dan pada tahap 2 rata-rata pada aspek metode inkuiri sebesar 85,71 dengan kriteria "baik" Sedangkan ahli materi pada aspek bahasa pada tahap 1 diperoleh rata-rata sebesar 60 dengan kriteria "cukup baik" dan pada tahap 2 diperoleh rata-rata sebesar 80 dengan kriteria "baik". Dari penjelasan di atas terdapat peningkatan dari msing-masing aspek yang divalidasi oleh ahli materi. Hal ini berarti modul sudah valid dan siap untuk digunakan pada ujicoba kelompok kecil dan ujicoba lapangan.

Berikut merupakan salah satu tampilan modul setelah divalidasi oleh ahli materi.
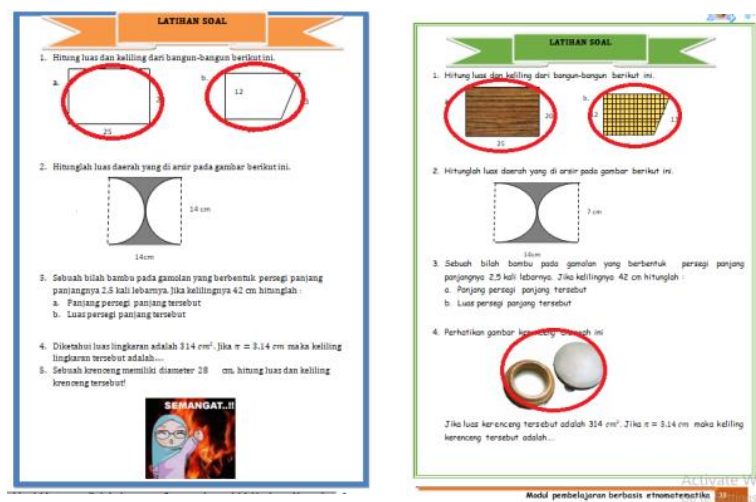

Gambar 2. Perbaikan Soal

Terlihat dari Gambar 2 sebelum revisi tidak terdapat cakupan etnomatematika dalam soal. Sedangkan setelah dilakukan revisi maka pada soal ditambahkan cakupan etnomatematika.
2) Hasil Validaasi Ahli Media

Hasil validasi oleh ahli media pada produk disajikan dalam bentuk grafik berikut:

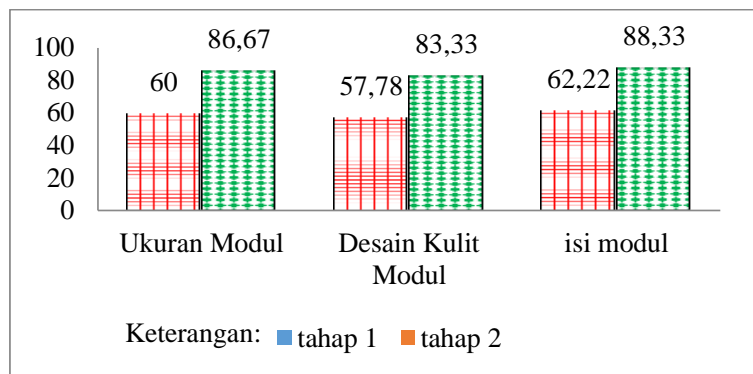

Gambar 3. Hasil validasi ahli media

Berdasarkan Gambar 3 diketahui bahwa hasil penilaian validasi ahli media tahap 1 mengalami peningkatan pada validasi ahli media tahap 2. Adapaun nilai untuk aspek ukuran modul pada tahap 1 diperoleh rata-rata 60 dengan kriteria "cukup baik" dan pada tahap 2 rata-rata aspek ukuran modul sebesar 86,67 dengan kriteria "baik". Rata-rata untuk aspek desain kulit modul pada tahap 1 adalah 57,78 dengan kriteria "cukup baik" dan pada tahap 2 rata-rata aspek desain kulit modul sebesar 83,33 dengan kriteria "baik". Sedangkan rata-rata aspek desain isi modul sebesar 62,22 dengan kriteria "cukup baik" dan pada tahap 2 rata-rata aspek desain isi modul sebesar 88,33 dengan kriteria "sangat baik". Terlihat dari grafik hasil validasi perbandingan antara validasi tahap 1 dan validasi tahap 2 masing-masing aspek mengalami peningkatan yang cukup baik dan sudah masuk dalam kriteria layak maka modul sudah valid dan tidak dilakukan perbaikan kembali. Berikut merupakan sampel dari tampilan pada cover modul menurt ahli media 
Desimal, 1 (2), 2018 - 125

Siti Mardiah, Rany Widyastuti, Achi Rinaldi
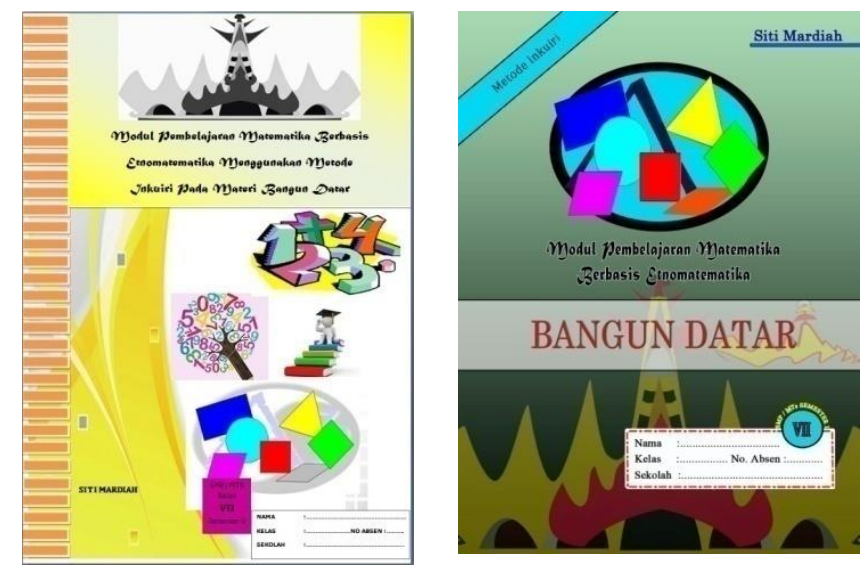

Gambar 4. Perubahan Tampilan Cover

b. Hasil uji coba Produk

1) Respon Peserta Didik

Hasil uji coba terkait kemenarikan dilakukan melalui dua tahapan yaitu uji kelompok kecil dan uji lapangan. Adapun hasil uji kelompok kecil diperoleh ratarata sebesar $85 \%$ dengan kriteria "menarik" dan pada uji lapangan dipeoleh rata-rata skor $87,28 \%$ dengan kriteria "sangat menarik". Perbandingan hasil uji coba dapat dilihat juga pada Gambar 4.12 berikut:

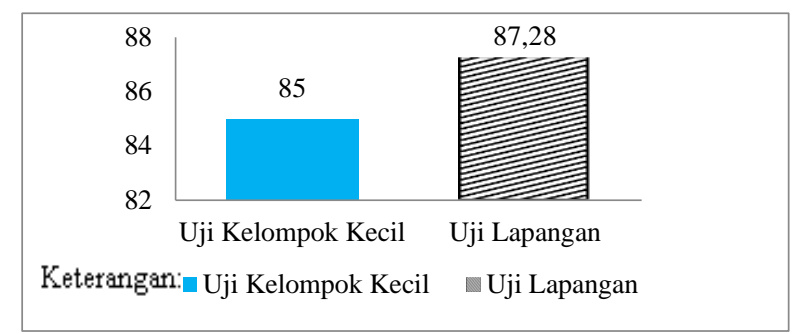

Gambar 5. Grafik Perbandingan Ujicoba Kelompok Kecil dan Uji Coba Lapangan

\section{2) Respon Pendidik}

Setelah melakukan uji coba kelompok kecil dan uji coba lapangan, kemudian produk diuji cobakan kembali ke uji coba guru. Uji coba guru ini dilakukan guna meyakinkan data dan mengetahui kemenarikan produk secara luas. Responden pada uji respon guru ini berjumlah 1 guru kelas VII. Hasil uji coba respon guru terhadap modul yang dikembangkan diperoleh rata-rata skor 86,15\% dengan kriteria sangat menarik, hal ini berarti Modul yang dikembangkan oleh peneliti mempunyai kriteria sangat menarik guna digunakan sebagai alat bantu dalam kegiatan belajar mengajar pada materi bangun datar.

\section{Dessiminate}

Tahap ini dilakukan peneliti dengan cara penyebaran terbatas dikarenakan menyesuaikan kebutuhan peneliti. Peneliti menyebarkan atau mempromosikan produk bahan ajar ini hanya di MTs Nurul Islam Jati Agung Lampung selatan sebagai tempat penelitian.

\section{SIMPULAN DAN SARAN}

Modul Pembelajaran Matematika Berbasis Matematika Mengguanakn Metode Inkuiri dikembangkan dengan model 4D yang dikembangkan oleh $\mathrm{S}$. Thigharajan, Dorothy Semmel, dan Melvyn I. Sammel yang meliputi tahap pendefinisian (Define), tahap perencanaan (design), tahap pengembangan (develop), dan tahap penyebaran (disseminate). Respon guru terhadap modul yang dikembangkan diperoleh rata-rata skor $86,15 \%$ dengan kriteria sangat menarik. Respon siswa terhadap modul diperoleh rata-rata skor 87,28\% dengan kriteria sangat menarik. Jadi modul pembelajaran matematika berbasis etnomatematika menggunakan metode inkuiri siap digunakan sebagai bahan ajar.

Berdasarkan hasil penelitian ini, selanjutnya diajukan saran-saran sebagai berikut: Bagi Guru modul pembelajaran matematika berbasis etnomatematika menggunakan metode inkuiri dapat dikembengkan dan menjadi salah satu alternatif bahan ajar dalam mengatasi kesulitan belajar siswa. Bagi Siswa modul pembelajaran matematika berbasis etnomatematika menggunakan metode inkuiri dapat diujicobakan terhadap 
subjek penelitian sehingga peneliti dapat mengetahui lebih luas tentang kemenarikan modul. Bagi Sekolah Pengembangan modul pembelajaran matematika menggunakan metode inkuiri dapat difasilitasi oleh sekolah agar modul ini dapat dikembangkan menjadi lebih baik lagi dan dapat menambah motifasi dan minat belajar matematika siswa.

\section{DAFTAR PUSTAKA}

Ade, F. Y. (2017). Pengembangan Media Pembelajaran Berbasis Virtual Class Berbantuan Google Drive. Tadris: Jurnal Keguruan Dan Ilmu Tarbiyah, 2(2), 121-129.

Anggoro, B. S. (2015). Pengembangan Modul Matematika Dengan Strategi Problem Solvin Guntuk Mengukur Tingkat Kemampuan Berpikir Kreatif Matematis Siswa. Al-Jabar: Jurnal Pendidikan Matematika, 6(2), 121130.

Asnawati, S., Liliana, I., \& Muhtarulloh, F. (2014). Penerapan Pembelajaran Inkuiri dengan Etnomatematik pada Materi Bidang Datar terhadap Kemampuan Pemahaman Matematis Siswa. Jurnal Euclid, 2(2), 275-295.

Fatikhah, I., \& Izzati, I. (2015). Pengembangan Modul Pembelajaran Matematika Bermuatan Emotion Quotient Pada Pokok Bahasan Himpunan. Eduma, 4(2), 46-61.

Musfiqi, S., \& Jailani, J. (2014). Pengembangan Bahan Ajar Matematika yang Berorientasi pada Karakter dan Higher Order Thinking Skill (HOTS). PYTHAGORAS: Jurnal Pendidikan Matematika, 9(1), 45-59.

Novitasari, E., Masykuri, M., \& Aminah, N. S. (2016). Pengembangan Modul Pembelajaran IPA Terpadu Berbasis Inkuiri Terbimbing Tema Matahari sebagai Sumber Energi Alternatif di Kelas VII SMP / MTs. JURNAL INKUIRI, 5(1).

Rosa, F. O. (2015). Pengembangan Modul Pembelajaran IPA SMP pada Materi Tekanan Berbasis Keterampilan Proses Sains. JPF, 3(1), 49-63.

S. Wijayanti, J. S. (2017). Pengembangan Perangkat Pembelajaran mengacu Model Creative Problem Solving berbasis Somatic, Auditory, Visualization, Intellectually. Al-Jabar: Jurnal Pendidikan Matematika, 8(2), 101-110.

Sugiyono. (2013). Metode Penelitian Pendidikan. Bandung: Alfabeta.

Supriadi, N. (2015). Mengembangkan Kemampuan Koneksi Matematis Melalui Buku Ajar Elektronik Interaktif (BAEI) yang Terintegrasi Nilai-Nilai Keislaman. Al-Jabar: Jurnal Pendidikan Matematika, 6(1), 63-73.

Trisianawati, E., \& Sari, I. N. (2017). Pembelajaran Inkuiri untuk Meningkatkan Keterampilan Proses Sains Calon Guru Fisika. Jurnal Ilmiah Pendidikan Fisika Al-BiRuNi, 6(2), 233-240.

Widyastuti, R. (2015). Proses Berpikir Siswa dalam Menyelesaikan Masalah Matematika berdasarkan Teori Polya ditinjau dari Adversity Quotient Tipe Climber. Al-Jabar: Jurnal Pendidikan Matematika, 6(2), 183-194.

Yusro, A. C., \& Sasono, M. (2016). Penggunaan Modul Ilustratif Berbasis Inkuiri Terbimbing Pokok Bahasan Kinematika Gerak Lurus untuk Meningkatkan Hasil Belajar dan Kemandirian Siswa Kelas VII SMPN 14 Madiun. Jurnal Pendidikan Fisika Dan Keilmuan (JPFK), 2(1), 2935. 